\title{
PERAN KELUARGA MENJAGA KESELAMATAN PASIEN DI RUANG RAWAT INAP RUMAH SAKIT
}

\author{
ANISYAH ISWARA \\ Fakultas Keperawatan Universitas Sumatera Utara \\ Email : anisyahiswara@gmail.com
}

\section{LATAR BELAKANG}

Rumah sakit adalah sarana pelayanan kesehatan yang dibutuhkan ketika seseorang sakit dan membutuhkan bantuan dengan tujuan untuk menyelamatkan kondisi pasien. Dengan seiring berjalannya waktu ilmu pengetahuan dan teknologi di rumah sakit mengalami perkembangan yang sangat signifikan sehingga rumah sakit tidak hanya dijadikan suatu tempat untuk menyelamatkan pasien, tetapi rumah sakit bisa dijadikan berbagai tempat pelayanan sehingga dapat diakses setiap pasien yang membutuhkan bantuan. Setiap pasien yang membutuhkan bantuan secara intensif selama beberapa hari dapat mengakses layanan ruang rawat inap rumah sakit. Perawatan untuk menjaga keselamatan pasien di ruang rawat inap rumah sakit memiliki peran penting dalam pelayanan perawatan untuk observasi,diagnosis, pengobatan atau upaya perawatan kesehatan lainnya. Keselamatan pasien di rumah sakit melibatkan partisipasi dari semua petugas kesehatan, terutama keluarga karena setiap pasien yang berada di ruang rawat inap rumah sakit pasti memiliki berbagai masalah kesehatan, sehingga pasien tersebut mengalami kesulitan untuk memenuhi kebutuhan pribadi termasuk menjaga keselamatan dirinya sendiri, oleh sebab itu setiap pasien membutuhkan peranan keluarga untuk menjaga keselamatan pasien di ruang rawat inap rumah sakit. Keluarga sebagai salah satu bagian dari pemberi pelayanan kepada pasien, karena keluarga mempunyai waktu yang panjang untuk berada disisi pasien ketika pasien mengalami masalah kesehatan dan peran keluarga juga dibutuhkan bagi setiap pasien yang berada di ruang rawat inap rumah sakit. Peran keluarga menjadi tolak ukur bagaimana sebuah keluarga dapat beroperasi sebagai unit dan bagaimana anggota keluarga berinteraksi dan berkomunikasi satu sama lain, sehingga dapat mencerminkan bagaimana timbulnya gaya pengasuhan, konflik yang terjadi pada keluarga, dan kualitas hubungan antara keluarga, selain itu peran keluarga sangat berpengaruh pada kapasitas kesehatan dan dapat menjaga keselamatan pasien di ruang rawat inap rumah sakit serta mempengaruhi kesejahteraan kesehatan keluarga.

Keluarga merupakan bagian dari suatu tim untuk melakukan pengobatan, perawatan serta menjaga keselamatan pasien diruang rawat inap rumah sakit. Karena negara kita sendiri memiliki sosial budaya yang tinggi dan di Indonesia memiliki keterbatasan jumlah perawat dan tenaga medis lainnya sehingga tugas memberikan pelayanan untuk merawat pasien yang berada di ruang rawat inap rumah sakit umumnya dilakukan oleh keluarga untuk menjaga pasien Peran keluarga terhadap pasien diruang rawat inap dapat berupa menjaga pasien secara bergantian, bahkan sering menjaga 
bersama-sama diruang rawat inap. Sementara perawat di rumah sakit yang memliki bebarapa tugas yang harus merawat pasien lain berada di bangsal perawatan. Maka, peran keluarga penting untuk memantau kebutuhan pasien dari laporan perawat atau jika perlu melakukan komunikasi langsung untuk dapat menjaga keselamatan pasien di ruang rawat inap rumah sakit. Rumah Sakit harus menjamin keselamatan pasien yang terkait dengan cedera pasien, cacat pasien serta yang berhubungan dengan pelayanan kesehatan.

\section{TUJUAN PENGKAJIAN}

Tujuan dari pengkajian ini adalah untuk mengetahui peran keluarga dalam penerapan menjaga keselamatan pasien di ruang rawat inap rumah sakit sehingga terlaksananya programprogram pencegahan kejadian tidak diharapkan pada setiap pasien misalnya cacat pada pasien,cedera pada pasien sehingga tidak terjadi pengulangan. Tujuan dari pengkajian ini dapat menambah wawasan tentang keselamatan pasien serta menganalisis pengaruh yang berhubungan dengan keselamatan pasien di ruang rawat inap rumah sakit antara peran keluarga dalam menjaga keselamatan pasien di rumah sakit, pada saat layanan kesehatan tidak memberikan pelayanan kepada pasien maka peran keluarga lah yang sangat dibutuhkan setiap pasien untuk menjaganya di ruang rawa inap rumah sakit dengan baik,karena keberhasilan perawat dan tenaga medis lainnya di rumah sakit tidak ada berguna jika tidak diteruskan oleh pihak keluarga ketika di rumah yang kemudian dapat mengakibatkan pasien harus dirawat kembali di ruang rawat inap rumah sakit. Peran keluarga pada saat awal di ruang rawat inap rumah sakit akan dapat meningkatkan kemampuan keluarga merawat pasien di rumah, sehingga memungkinkan pasien untuk sembuh dari masalah penyakit yang diderita setiap pasien serta menghindarkan kejadian yang tidak diharapkan misalnya cacat pada pasien,cedera pada pasien sehingga dapat terwujudnya keselamatan pasien di ruang rawat inap rumah sakit.

\section{METODE PENELITIAN}

Metode yang digunakan adalah metode kualitatif yaitu dengan cara "Literature Review dimana maksudnya dengan cara mengumpulkan beberapa data, menganalisis dan melakukan pengkajian dengan menggunakan jurnal, teksbook, google scholar yang berfokus pada metode pembelajaran yang berhubungan dengan peran keluarga menjaga keselamatan pasien di ruang rawat inap rumah sakit sehingga jurnal, text book, google scholar yang digunakan dalam pengkajian dapat digunakan untuk mengetahui peran keluarga dalam menjaga keselamatan pasien di ruang rawat inap rumah sakit serta mengetahui bagaimana tingkat peran keluarga dalam menjaga keselamatan pasien diruang rawat inap yang digunakan untuk menerapkan keselamatan pasien sehingga tidak terjadi kejadian yang tidak diharapkan misalnya cacat pasien dan cedera pada pasien 


\section{HASIL}

Berdasarkan dari tinjauan literatur tersebut dapat disimpulkan bahwa hasil penelitian ini menjawab seluruh tujuan dalam penelitian. Hasil penelitian ini meliputi pengkajian data tentang Peran keluarga menjaga keselamatan pasien di ruang rawat inap rumah sakit. Dalam penelitian tinjauan literatur beberapa metode pengumpulan data dapat bertujuan untuk meningkatkan kemampuan keluarga dalam menjaga keselamatan pasien dan dapat mengindari kejadian yang tidak diharapkan pada pasien misalnya cacat pada pasien dan cedera pada pasien, Sehingga keselamatan pasien dapat diterapkan oleh keluarga kepada pasien

\section{PEMBAHASAN}

Rumah Sakit dalam upaya memberikan pelayanan kesehatan melibatkan tim kerja dari berbagai profesi, maka rumah sakit menyiapkan sistem layanan terintegrasi yang berfokus pada pasien untuk memberi pelayanan yang aman dengan enam sasaran keselamatan pasien yaitu Ketepatan identifikasi pasien, Komunikasi efektif, Pemberian obat secara aman, Ketepatan pasien, lokasi dan prosedur operasi, Pencegahan infeksi, Pencegahan pasien jatuh. Dalam menjaga keselamatan pasien di ruang rawat inap rumah sakit diperlukannya kerja sama dengan keluarga. Keluarga merupakan unit terkecil dalam masyarakat dan keluarga didefinsikan dengan istilah kekerabatan dimana invidu bersatu dalam suatu ikatan perkawinan dengan menjadi orangtua. Dalam arti luas anggota keluarga merupakan mereka yang memiliki hubungan personal dan timbal balik dalam menjalankan kewajiban dan memberi dukungan yang disebabkan oleh kelahiran,adopsi,maupun perkawinan (Stuart,2014)

Menurut Duval keluarga merupakan sekumpulan orang yang dihubungkan oleh ikatan perkawinan,adopsi,kelahiran yang bertujuan menciptakan dan mempertahankan upaya yang umum,meningkatkan perkembangan fisik mental,emosional dan social dari tiap anggota keluarga (Harnilawati,2013).

Menurut Helvie keluarga adalah sekelompok manusia yang tinggal dalam satu rumah tangga dalam kedekatan yang konsisten dan hubungan yang erat. Keluarga adalah dua atau lebih individu yang tergabung karena hubungan darah,hubungan perkawinan atau pengangkatan dan mereka hidup dalam satu rumah tangga,berinteraksi satu sama lain dan didalam perannya masing masing menciptakan serta mempertahankan kebudayaan (Friedman,2010) Sehingga dapat ditarik kesimpulan bahwa keluarga merupakan sekumpulan orang yang dihubungkan melalui ikatan perkawinan,darah,adopsi serta tinggal dalam satu rumah. Peran keluarga secara aktif dalam menjaga keselamatan pasien di rawat inap rumah sakit sebagai berikut :

1. Memberikan informasi yang benar, jelas, lengkap dan jujur

2. Mengetahui dan melaksanakan kewajiban serta tanggung jawab pasien maupun keluarga.

3. Mengajukan pertanyaan-pertanyaan untuk hal yang tidak dimengerti.

4. Memahami dan menerima konsekuensi pelayanan. 
5. Mematuhi dan menghormati peraturan rumah sakit.

6. Memperlihatkan sikap menghormati dan tenggang rasa dalam proses bersama tim kesehatan mengelola pasien

7. Memenuhi kewajiban finansial yang disepakati.

Keselamatan (safety) telah menjadi isu global termasuk di rumah sakit. Ada enam sasaran keselamatan pasien di rumah sakit yaitu ketepatan identifikasi, peningkatan komunikasi efektif, peningkatan keamanan obat yang perlu diwaspadai, kepastian tepat lokasi, tepat prosedur, tepat pasien operasi, pengurangan resiko infeksi terkait pelayanann kesehatan pengurangan resiko pasien jatuh (Depkes,2011) Penerapan enam sasaran keselamatan pasien dan peran keluarga dalam menjaga keselamatan pasien rawat inap di rumah sakit antara lain sebagai berikut :

\section{Ketepatan Identifikasi Pasien}

Pasien dalam keadaan tidak sadar, gelisah, mengalami gangguan penglihatan, gangguan pendengaran, gangguan proses pikir, mendapat obat bius, atau gangguan lain tidak mampu melakukan identifikasi diri dengan benar selain itu pasien yang pindah ruang rawat atau bertukar tempat tidur saat perawatan di rumah sakit berisiko mengalami ketidaktepatan identifikasi, maka rumah sakit menyusun sistem untuk memastikan identifikasi pasien sebagai individu yang akan menerima pelayanan adalah tepat dan jenis pelayanan atau pengobatan terhadap individu tersebut adalah sesuai.

Peran Pasien dan keluarga untuk memastikan ketepatan identifikasi pasien adalah:

a. Memberikan data diri yang tepat pada saat mendaftar sesuai dokumen data diri yang dimiliki. Data utama yang diperlukan adalah nama dan tanggal lahir

b. Selama rawat inap pasien dipakaikan gelang. Pasien dan keluarga harus memahami fungsi gelang dan patuh menggunakan gelang tersebut selama rawat inap karena gelang tersebut dipakai oleh tim kesehatan guna memastikan kebenaran identitas dan faktor risiko pasien saat memberikan pelayanan.

- Gelang warna biru untuk laki-laki dan gelang warna merah muda untuk perempuan dipakai untuk identifikasi

- Gelang warna merah dipasangkan pada pasien yang memiliki riwayat alergi

- Gelang warna kuning dipasangkan pada pasien yang memiliki risiko jatuh

c. Pasien atau keluarga kooperatif saat dilakukan verifikasi identitas oleh petugas saat akan melakukan tindakan, memberikan obat, mengambil preparat untuk pemeriksaan laborat dan lain-lain. 


\section{Komunikasi efektif}

Pasien yang menjalani rawat inap dikelola oleh dokter dan berbagai profesi lain sebagai tim dengan menerapkan sistem komunikasi yang efektif untuk memberikan pelayanan

Peran pasien dan keluarga mewujudkan komunikasi efektif adalah:

a. Menunjuk atau menetapkan anggota keluarga yang diberi kewenangan untuk berkomunikasi dengan tim kesehatan. Penunjukkan ini diperlukan untuk memastikan komunikasi berlangsung efektif dan berkesinambungan, tidak mengalami rantai komunikasi yang panjang dan kompleks yang berisiko menyebabkan perubahan makna isi informasi.

b. Memberikan informasi dan data terkait kondisi pasien kepada tim kesehatan dengan benar dan jelas.

c. Memberikan informasi pada petugas bila ada kejadian tidak diharapkan.

d. Meminta informasi yang diperlukan kepada tim kesehatan

\section{Pemberian obat secara aman}

Pemberian obat merupakan bagian yang mengambil porsi dominan dalam mengelola pasien rawat inap..

Peran serta keluarga dalam menjamin keamanan pemberian obat adalah :

a. Memberikan informasi yang lengkap tentang riwayat obat yang pernah dipergunakan sebelum masuk rumah sakit

b. Memberikan informasi tentang riwayat alergi atau reaksi yang dialami saat menggunakan obat tertentu

c. Mendukung pengawasan pemberian obat selama rawat inap dengan cara memastikan identitas pasien benar, menanyakan jenis obat yang diberikan, tujuan pemberian, dosis dan waktu pemberian obat

\section{Kepastian Tepat-Lokasi, Tepat-Prosedur, Tepat-Pasien Operasi}

Tindakan operasi merupakan salah satu prosedur yang mungkin dilakukan pada pasien untuk mengatasi masalah kesehatannya. Bagian tubuh yang akan dioperasi bisa meliputi bagian yang bersisi (misalnya tangan atau kaki kanan dan kiri, mata kanan dan kiri) atau bagian yang multipel level (misalnya tulang belakang) atau bagian yang multipel struktur (misalnya jari tangan) dengan demikian diterapkan sistem untuk memastikan tindakan tepat-lokasi, tepat-prosedur, tepat-pasien

Salah satu prosedur yang dilakukan sebelum tindakan operasi adalah proses verifikasi. Peran pasien dan keluarga dalam proses verifikasi praoperasi adalah memberikan informasi yang benar dan bekerja sama secara kooperatif 
a. Verifikasi lokasi, prosedur, dan pasien yang benar

Proses ini dilakukan dengan membuat tanda pada lokasi yang dioperasi. Penandaan lokasi operasi ini melibatkan pasien, dibuat oleh dokter yang akan melakukan tindakan dan dilaksanakan saat pasien dalam keadaan sadar .Tanda ini tidak boleh dihapus dan harus terlihat sampai saat akan disayat.

b. Memastikan bahwa semua dokumen, foto (imaging), hasil pemeriksaan yang relevan tersedia, diberi label dengan baik

c. Melakukan verifikasi ketersediaan peralatan khusus yang dibutuhkan.

\section{Pengurangan risiko infeksi terkait pelayanan kesehatan}

Rumah sakit merupakan tempat yang memungkinkan berkumpulnya berbagai jenis kuman sedangkan pasien yang sedang dirawat memiliki daya tahan tubuh relatif rendah dengan demikian diperlukan suatu proses bersama untuk mencegah timbulnya infeksi lain yang tidak berhubungan dengan penyakit utama pasien

Peran pasien dan keluarga dalam pengurangan risiko terkait pelayanan kesehatan adalah

a. Menerapkan prosedur cuci tangan yang benar

Keluarga memiliki kemungkinan sering kontak dengan pasien, maka untuk melindungi diri sendiri dan melindungi pasien dari perpindahan kuman disarankan keluarga menerapkan prosedur cuci tangan yang benar pada 5 (lima) momen yaitu saat sebelum kontak dengan pasien, sesudah kontak pasien, sesudah ke toilet, sebelum dan sesudah makan. Perlu diperhatikan juga bahwa lingkungan sekitar pasien berisiko terpapar kuman maka disarankan mencuci tangan sesudah kontak dengan lingkungan pasien (meja, alat tenun, tempat tidur dsb),

Guna memperoleh hasil cuci tangan yang optimal Pasien dan keluarga disarankan mencermati dan mengikuti petunjuk 6 (enam) langkah mencuci tangan yang diberikan oleh petugas atau panduan cuci tangan yang ada di rumahsakit

b. Membatasi pengunjung pasien

Selama pasien dirawat di rumah sakit seyogyanya pasien tidak berinteraksi dengan banyak orang karena berisiko terpapar kuman dari pengunjung dalam keadaan pertahanan diri yang relatif rendah dengan demikian peran keluarga diperlukan untuk membatasi pengunjung yang kontak dengan pasien

c. Menerapkan etika batuk yang benar

Keluarga dan pengunjung yang batuk berisiko menyebarkan kuman melalui partikel halus di udara dengan demikian bila sedang mengalami batuk keluarga perlu menggunakan masker atau menerapkan tehnik perlindungan yang benar saat batuk yaitu menutup mulut dan hidung menggunakan lengan. 


\section{Pengurangan Risiko Pasien Jatuh}

Individu yang sedang sakit memiliki keterbatasan dalam pengamanan diri termasuk menghindari jatuh. Rumah sakit mengambil tindakan untuk mengurangi risiko dengan melakukan pengkajian faktor-faktor yang dapat menyebabkan jatuh seperti, penggunaan obat, gaya jalan dan keseimbangan, alat bantu berjalan yang digunakan oleh pasien, riwayat jatuh saat berjalan atau saat istirahat baring di tempat tidur.

Peran pasien dan keluarga dalam mencegah jatuh saat dirawat di rumah sakit adalah

a. Pastikan penanda pasien beresiko jatuh berupa gelang kuning dipakai pasien

b. Jangan melepas atau memindah kartu kuning yang dipasang petugas dekat tempat tidur pasien atau di depan kamar pasien karena kartu tersebut merupakan penanda untuk mewaspadai pasien yang beresiko jatuh

c. Keluarga atau pasien perlu memastikan diri untuk memahami informasi yang diberikan oleh petugas agar dapat mendukung tindakan pencegahan jatuh.Informasi yang perlu diketahui adalah:

○ faktor resiko jatuh yang teridentifikasi seperti obat yang dipergunakan, kesadaran pasien, keseimbangan saat berjalan,dll

- tindakan pencegahan jatuh yang perlu dilakukan

o cara untuk minta bantuan

- cara menggunakan bel atau sarana komunikasi di ruangan

$\circ$ cara mengatur pengamanan tempat tidur

$\bigcirc$ pengggunaan tali pengaman, dll

Pengelolaan pasien rawat inap tidak hanya mejadi tanggung jawab tim kesehatan tetapi melibatkan juga pribadi pasien sendiri dan keluarga, maka setiap bagian perlu menjalankan peran masing-masing sesuai tugasnya karena proses kerja sama yang baik merupakan dasar yang kuat untuk memperoleh hasil optimal.

Keselamatan Pasien adalah suatu sistem yang membuat asuhan pasien lebih aman,meliputi asesmen risiko, identifikasi dan pengelolaan risiko pasien, pelaporan dan analisis insiden, kemampuan belajar dari insiden dan tindak lanjutnya, serta implementasi solusi untuk mengurangi timbulnya risiko dan mencegah terjadinya cedera yang disebabkan oleh kesalahan akibat melaksanakan suatu tindakan atau tidak mengambil tindakan yang seharusnya diambil. (permenkes tahun 2017)

Petugas kesehatan dalam melaksanakan tugas sebagaimana dimaksud pada ayat (1), Komite Nasional Keselamatan Pasien menyelenggarakan fungsi :

a. penyusunan standar dan pedoman keselamatan Pasien;

b. penyusunan dan pelaksanaan program keselamatan Pasien; 
c. pengembangan dan pengelolaan sistem pelaporan Insiden, analisis, dan penyusunan rekomendasi Keselamatann Pasien;

d. kerja sama dengan berbagai institusi terkait baik dalam maupun luar negeri; dan

e. monitoring dan evaluasi pelaksanaan program keselamatan pasien.Standar keselamatan pasien sebagaimana dimaksud pada ayat (2) huruf a meliputi standar :

a. hak pasien;

b. pendidikan bagi pasien dan keluarga;

c. keselamatan pasien dalam kesinambungan pelayanan;

d. penggunaan metode peningkatan kinerja untuk melakukan evaluasi dan peningkatan keselamatan pasien;

e. peran kepemimpinan dalam meningkatkan keselamatan pasien;

f. pendidikan bagi staf tentang keselamatan pasien; dan

g. komunikasi merupakan kunci bagi petugas kesehatan untuk mencapai keselamatan pasien.

\section{PENUTUP}

Keselamatan pasien (patient safety) adalah hal terpenting yang perlu diperhatikan oleh keluarga pasien yang terlibat dalam memberikan pelayanan kesehatan kepada pasien.Tindakan pelayanan, peralatan kesehatan, dan lingkungan sekitar pasien sudah seharusnya menunjang keselamatan serta kesembuhan dari pasien tersebut.Oleh karena itu, keluarga pasien harus memiliki pengetahuan mengenai hak pasien serta mengetahui secara luas dan teliti tindakan pelayanan yang dapat menjaga keselamatan diri pasien di ruang rawat inap rumah sakit serta menjadikan komunikasi sebagai kunci utama untuk dapat memberikan kenyamanan dan keselamatan bagi pasien.

Keluarga merupakan bagian dari suatu tim untuk melakukan pengobatan, perawatan serta menjaga keselamatan pasien diruang rawat inap rumah sakit. Karena negara kita sendiri memiliki sosial budaya yang tinggi dan di Indonesia memiliki keterbatasan jumlah perawat dan tenaga medis lainnya sehingga tugas memberikan pelayanan untuk merawat pasien yang berada di ruang rawat inap rumah sakit umumnya dilakukan oleh keluarga untuk menjaga pasien maka dari itu keluarga pasien harus diberikan pengetahuan tentang bagaimana cara menjaga keselamatan pasien di rua ng rawat inap rumah sakit sehingga pada saat dirumah sakit maupun di rumah pasien dapat terhindar dari kejadian yang tidak terduga misalnya cedera pada pasien dan cacat pada pasien. 


\section{DAFTAR PUSTAKA}

1. Simamora, R. H. (2020). Learning of Patient Identification in Patient Safety Programs Through Clinical Preceptor Models. Medico Legal Update, 20(3), 553-556.

2. Simamora, R. H. (2018). Buku ajar keselamatan pasien melalui timbang terima pasien berbasis komunikasi efektif: SBAR. Medan: USUpress.

3. Komang, A.H. (2006). Asuhan keperawatan keluarga

4. 2.Marylin M. Friedman Friedman ;Vicky R. Bowden, Elaine G Jones(2010). Buku ajar keperawatan keluarga, Riset, Teori dan Praktik.Edisi 5. Jakarta, EGC

5. Simamora, R.H. (2019). Buku Ajar : Pelaksanaan Identifikasi Pasien. Ponorogo, Jawa Timur: Uwais Inspirasi Indonesia.

6. Najihah. (2018). Budaya Keselamatan Pasien dan Insiden Keselamatan Pasien Di Rumah Sakit: Literature Review. Journal Of Islamic Nursing. 3 (1), 1-4.

7. Neri, R., A., Lestari, Y., \& Yetty, H. (2018). Analisis Sasaran Pelaksanaan Keselamatan Pasien di Rawat Inap Rumah Sakit Umum Daerah Padang Pariaman. Jurnal Kesehatan Andalas. 7 (4), 48-50

8. Yahya, Adib A. (2006) Konsep dan Program “Patient Safety". Proceedings of National Convention VI of The Hospital Quality Hotel Permata Bidakara, Bandung 14-15 November 2006

9. Potter, P. A and Perry, A. G. (2005).Buku Ajar Fundamental Keperawatan: Konsep, Proses,dan Praktik Edisi 4 Volume 1.Penerjemah Yasmin Asih, dkk.Jakarta : Salemba Medika.

10. Ismainar, H. (2019). Keselamatan Pasien di Rumah Sakit. Yogyakarta: Deepublish

11. Putri, S., Santoso, S., \&Rahayu, E. P. (2018).Pelaksanaan Keselamatan Pasien dan Kesehatan Kerja terhadap Kejadian Kecelakaan Kerja Perawat Rumah Sakit. Jurnal Endurance: KajianIlmiahProblemaKesehatan, 3(2), 271-277

12. Kemenkes RI. (2011). Permenkes RI No.1691/Menkes/VIII/2011 tentang Keselamatan Pasien Rumah Sakit. 